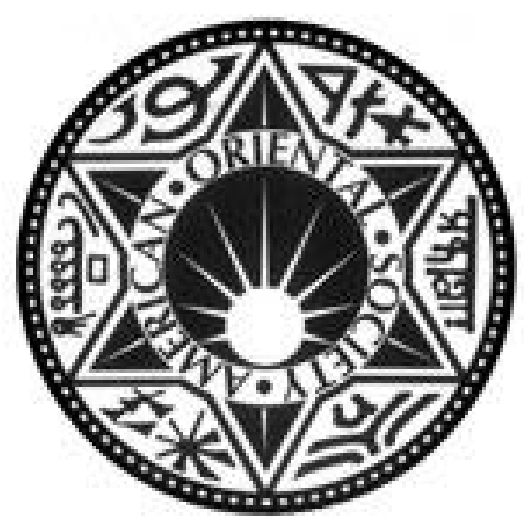

The Inquisition outside Baghdad

Author(s): Christopher Melchert

Source: Journal of the American Oriental Society, January-March 2021, Vol. 141, No. 1 (January-March 2021), pp. 201-210

Published by: American Oriental Society

Stable URL: https://www.jstor.org/stable/10.7817/jameroriesoci.141.1.0201

JSTOR is a not-for-profit service that helps scholars, researchers, and students discover, use, and build upon a wide range of content in a trusted digital archive. We use information technology and tools to increase productivity and facilitate new forms of scholarship. For more information about JSTOR, please contact support@jstor.org.

Your use of the JSTOR archive indicates your acceptance of the Terms \& Conditions of Use, available at https://about.jstor.org/terms 


\title{
The Inquisition outside Baghdad
}

\author{
CHRISTOPHER MELCHERT \\ UNIVERSITY OF OXFORD
}

\begin{abstract}
The Inquisition (mihna) of al-Ma'mūn (d. 218/833) was a serious attempt to establish the caliph as arbiter of Islamic orthodoxy. It was actively prosecuted by the succeeding two caliphs, and finally abolished by his nephew, the caliph al-Mutawakkil, in 237/852. The most information we have about it by far is how it was carried out in Baghdad. Various sources, mostly biographical, also tell us something of its prosecution in Basra, Kufa, Damascus, Isfahan, Old Cairo (Fustat), and Qayrawan, surveyed here. These scattered data confirm that it was largely about bringing the emerging scholarly class under control. They may also indicate that the Inquisition was instituted not in 218 but already in 217/832-3.
\end{abstract}

The Inquisition (mihna) of al-Ma'mūn (d. 218/833) was a serious attempt to establish the caliph as arbiter of Islamic orthodoxy. It took the form of demanding that the ulema assent to the caliph's doctrine that the Quran was created. The two caliphs after al-Ma'mūn, his halfbrother al-Mu'tașim (r. 218-227/833-842) and his nephew al-Wāthiq (r. 227-232/842-847), maintained the Inquisition, but it was abolished under the subsequent caliph al-Mutawakkil by stages from 232 to 237/847 to 852. An American scholar, Walter M. Patton, published a competent survey of it already at the end of the nineteenth century. ${ }^{1}$ Josef van Ess is to be credited with the chief further advance in our understanding of it, namely, that it was principally political and that al-Ma'mūn's policy was more securely identified with the Hanafi school than, as formerly thought, the Mu'tazili. ${ }^{2}$ Apart from some remarks on al-Wāthiq and al-Mutawakkil, minor adjustments have been made since Martin Hinds's summary treatment in The Encyclopaedia of Islam. ${ }^{3}$ The present survey of the Inquisition outside Baghdad offers a few more minor adjustments, mainly to its date and political significance.

1. W. M. Patton, Ahmed ibn Hanbal and the Mihna: A Biography of the Imâm Including an Account of the Mohammedan Inquisition Called the Mihna, 218-234 A.H. (Leiden: E.J. Brill, 1897), repr. as an appendix to J. A. Nawas, Al-Ma'mūn, the Inquisition, and the Quest for Caliphal Authority, Resources in Arabic and Islamic Studies, vol. 4 (Atlanta: Lockwood Press, 2015).

2. J. van Ess, "Dirār b. 'Amr und die 'Cahmīya': Biographie einer vergessenen Schule," Der Islam 43 (1967): 241-79; 44 (1968): 1-70, 318-20; idem, "Ibn Kullāb und die Miḥna," Oriens 18-19 (1965-66): 92-141, trans. with additional notes by Cl. Gilliot, "Ibn Kullāb et la Mị̣na," Arabica 37 (1990): 173-233.

3. M. Hinds, "Miḥna," in Encyclopaedia of Islam, new edn., 12 vols., 7: 2-6. The second-century AH background was filled out by W. Madelung, "The Origins of the Controversy Concerning the Creation of the Koran," in Orientalia hispanica: Sive studia F. M. Pareja octogenario dicata, ed. J. M. Barral (Leiden: E.J. Brill, 1974), 504-25. On al-Wāthiq and al-Mutawakkil, see esp. J. P. Turner, "The Enigmatic Reign of al-Wāthiq," 'Abbasid Studies IV, ed. M. Bernards (n.p.: Gibb Memorial Trust, 2013), 218-31; and Ch. Melchert, "Religious Policies of the Caliphs from al-Mutawakkil to al-Muqtadir," Islamic Law and Society 3 (1996): 316-42, at 318-30. An outstandingly comprehensive summary is F. Jad'ān, al-Mihnna: Baḥth fì jadaliyyat al-dīñ̄ wa-l-siyāsī fì al-Islām (Amman: Dār al-Shurūq, 1989); see also J. A. Nawas, "A Reexamination of Three Current Explanations for al-Ma'mūn's Introduction of the mihna," International Journal of Middle East Studies 26 (1994): 615-29; and Nawas's book cited in n. 1. Caliphal persecution before and after the quranic Inquisition is surveyed by J. P. Turner, Inquisition in Early Islam: The Competition for Political and Religious Authority in the Abbasid Empire, Library of Middle East History, vol. 35 (London: I.B. Tauris, 2013). For more titles, see John Nawas's helpful annotated bibliography at www.oxfordbibliographies.com (accessed 19 July 2019).

Journal of the American Oriental Society 141.1 (2021) 


\section{IN IRAQ OUTSIDE BAGHDAD}

In Basra, Abū Mūsā 'Abbās ibn 'Abd al-'Aẓ̄̂m al-'Anbarī (d. 246/860-1) and 'Alī ibn al-Madīn̄i (d. 234/849) were examined. 'Īsā ibn Abān ibn Șadaqa (d. 221/836?), appointed by al-Ma'mūn in 211/826, was evidently the qadi for Basra at the start of the Inquisition. ${ }^{4}$ 'Abbās al-'Anbarī was made to stand (uqīma) and chastised with the whip, and so answered as bidden. 'Alī ibn al-Madīn̄ì was present, and when he saw what had befallen 'Abbās, he answered without his being chastised in turn. Following Q 16:106 ("Whoever disbelieves in God after being a believer - except in the case of those who are forced and whose hearts are still at rest in their belief' - trans. Jones), Aḥmad ibn Ḥanbal excused 'Abbās as having been forced, but would not excuse 'Alī ibn al-Madīn̄i. ${ }^{5}$

Al-Khațīb al-Baghdādī relates a story in which Abū Nu'aym al-Faḍl ibn Dukayn (d. 219/834?) of Kufa was examined before the governor. Also present were Ibn Abī Hanīfa (a grandson or great-grandson of Abū Ḥanīfa), Aḥmad ibn Yūnus, Abū Ghassān (Mālik ibn Ismā'īl, d. 219/834), and others. ${ }^{6}$ Ibn Abī Hanīfa, who was the first to be examined, testified that the Quran was created. Abū Nu'aym, next up, dismissed Abū Ḥanīfa as a zindī $q$ (secret unbeliever) and expressed contempt of the governor's power to execute him: "I have heard seven hundred shaykhs in Kufa say the Quran is the speech of God. My neck is worth less to me than this button," which he had cut off and now held up. Ahmad ibn Yūnus rose up and kissed the old man. ${ }^{7}$

According to Wakī $\bar{c}^{\complement}$, Ghassān ibn Muhammad (d. after 235/849-50), close to the vizier Ibn Abī Duwād and appointed qadi of Kufa by al-Mu'tașim, prosecuted the Inquisition. ${ }^{8}$ Ismā'̄i l ibn Hammād, the actual grandson of Abū Hanīfa, is said to have died in 212/827-8, the year al-Ma'mūn announced as official doctrine that the Quran was created but years before he launched the Inquisition. I therefore suppose that it was a son of his present at $\mathrm{Abu}$ Nu'aym's examination. However, it is possible that Ismāc̄il ibn Hammād was merely quoted there, having declared in the palace of al-Ma'mūn, "The Quran is created, this being my faith, my father's faith, and my grandfather's." 9

Of the others, I have been able to discover no other information concerning Ahmad ibn Yūnus. His reputation as a traditionist cannot have been great. Abū Ghassān was a moderate Shici, a follower of al-Ḥasan ibn Șālih ibn Ḥayy (d. 169/785-6?), and a respected traditionist (in all of the Six Books). ${ }^{10} \mathrm{He}$ affirmed that the Quran was created, but only, it is said, to

4. Wakī̄', Akhbār al-qud̄āh, ed. 'A. M. al-Marāghī, 3 vols. (Cairo: Mațba'at al-Istiqāma, 1366-69/1947-50), 3 : 170; al-Khațīb al-Baghdādī, Tārīkh Madīnat al-Salām, ed. B. 'A. Ma'rūf, 17 vols. (Beirut: Dār al-Gharb al-Islāmī, 1422/2001), 12: 481 citing Ibn Sa'd, apparently his chronicle (Tārīkh).

5. Hanbal ibn Isḥāq, Dhikr mịhnat al-imām Aḥmad ibn Hanbal, ed. M. Naghash (Cairo: Dār Nashr al-Thaqāfa, 1397/1977), 38-39 = K. al-Mihnna, ed. M. al-Qabbānī, Silsilat tạ̣qīq al-turāth, vol. 39 (Riyadh: Markaz al-Malik Fayșal li-l-Buhūth wa-l-Dirāsāt al-Islāmiyya, 1440/2019), 87.

6. Al-Khațīb al-Baghdādī, Tārīkh, 14: 310.

7. Al-Khațīb al-Baghdādī, Tārīkh, 14: 310-11. In another version (loc. cit.), he said he had heard three hundred shaykhs who said the Quran was the speech of God and uncreated, and cited his button not at court but in conversation with Abū Bakr ibn Abī Shayba, who had come to warn him of what was coming.

8. Wakī̄ $, A k h b \bar{a} r, 3: 191$. Ghassān ibn Muḥammad was incumbent 218?-235, according to Nurit Tsafrir, who classifies him as "Hanafi?": The History of an Islamic School of Law: The Early Spread of Hanafism, Harvard Series in Islamic Law, vol. 3 (Cambridge, MA: Islamic Legal Studies Program, Harvard Law School, 2004), 30.

9. Al-Khațīb al-Baghdādī, Tārīkh, 14: 310-11; similarly, 'Abd Allāh ibn Aḥmad, K. al-Sunna, ed. A. 'A. Āl Hamdān, Silsilat kutub al-sunna wa-l-i'tiqād, vol. 1 (n.d.: n.p., 1437), 128. This latter account is from a section on the errors of Abū Hanīfa missing from the manuscript on which earlier editions were based.

10. Al-Dhahabī, Tārīkh al-islām, ed. 'U. 'A. Tadmurī, 52 vols. (Beirut: Dār al-Kitāb al-'Arabī, 1407-21/19872000), 15 (211-220 AH): 402-3 with further references. 
save his life, not from belief. ${ }^{11} \mathrm{Abu} \mathrm{Nu}^{\mathrm{C}}$ aym is said to have been brought before al-Ma'mūn around the time of his first coming to Baghdad as well (204/819), when he had rebuked a soldier for misbehaving with a woman in defiance of al-Ma'mūn's decree forbidding al-amr bi-l-ma' rüf wa-l-nahy 'an al-munkar ("commanding right and forbidding wrong"). ${ }^{12}$ Moreover, Abū al-'Arab relates an account of Abū Nu'aym's examination that expressly locates it in 217/832-3, a year before the well-known events in Baghdad, although still in response to a letter from al-Ma'mūn. ${ }^{13}$

\section{IN THE HIJAZ}

In Medina, two former students of Mālik, Abū Bakr ibn Abī Uways ('Abd al-Ḥamīd ibn 'Abd Allāh) and Muṭarrif ibn 'Abd Allāh, received a summons related to the Inquisition concerning the Quran. There is no report of what Mutarrif said. A purported eyewitness said that on having the letter read to them (the letter of institution from al-Ma'mūn, no doubt), Abū Bakr replied, "Will I be an ingrate toward God after ninety-odd years, and sitting with Mālik ... ?" He was told, "Let your house be your prison"; that is, he was put under house arrest. ${ }^{14}$ A difficulty with the story is that whereas Mutarrif is said to have died in 220/835, Abu Bakr is said to have died already in 202/817-18. ${ }^{15}$ Possibly he was put under house arrest in connection not with the Inquisition but with opposition to al-Ma'mūn during the Fourth Civil War. Abū Bakr's brother Ismā̄îl ibn Abī Uways (d. 227/842?), more renowned but less well regarded, is quoted as angrily refusing (on another occasion) to discuss the question. ${ }^{16}$ Aḥmad complimented him for taking an honorable position. ${ }^{17}$

As for Mecca, Hanbal ibn Isḥāq (d. 273/886) saw signs on the walls around the $\mathrm{Ka}^{\mathrm{c}} \mathrm{ba}$ in 221/836 proclaiming, "There is nothing like him, the Gentle and Informed (al-latîf al-khabir)." ${ }^{18}$ Ahmad ibn Hanbal commented bitterly that they had stricken "the Hearing and Observing" from their quotation; that is, they had tendentiously mixed words from Q 22:61 and 42:11 so as to stress transcendence but avoid an anthropomorphic attribution of sensory perception. ${ }^{19}$ However, I have not come across any biographical notices of Meccans subjected to the Inquisition.

11. Abū al-'Arab, K. al-Miḥan, ed. Y. W. al-Jubūrī (Beirut: Dār al-Gharb al-Islāmīi, 1403/1983), 445.

12. Al-Khațīb al-Baghdādī, Tārīkh, 14: 311-12; see also M. Cook, Commanding Right and Forbidding Wrong in Islamic Thought (Cambridge: Cambridge Univ. Press, 2000), 70-71.

13. Abū al-'Arab, Mihan, 444-45.

14. Al-Qāḍ̄ī 'Iyāộ, Tartīb al-madārik, ed. M. al-Ṭanjī et al., 8 vols. (Rabat, etc.: various, 1966-83), 3: 156, mostly on the basis of Ahmad al-Taymī, K. al-Mihan.

15. Al-Bukhārī, al-Tārīkh al-awsaț, ed. M. I. al-Luhaydān, 2 vols., Silsilat kutub al-tawārīkh wa-l-tarājim, vol. 2 (Riyadh: Dār al-Șumay'ī, 1418/1998), 2: 242; idem, al-Tārīkh al-kabīr, 8 vols. (Hyderabad: Maṭba'at Dā'irat al-Ma`ārif al-Nizāmiyya, 1941-45; repr. 9 vols, Beirut: Dār al-Kutub al-`Ilmiyya, n.d.), 6: 50-51; Ibn Hibbān, K. al-Thiqāt, ed. M. 'A. Khān, 9 vols. (Hyderabad: Maṭba'`at Dā’irat al-Ma'ārif al-'Uthmāniyya, 1393-1403/197383), 8: 398.

16. Al-Qāḍ̄i 'Iyāḍ, Tartī̄b, 3:154.

17. Al-Dhahabī, Tārīkh, 16 (221-230 AH): 93.

18. There is also a report that several years later the qadi Ibn Abī al-Layth ordered the slogan to be written on the walls of Egyptian mosques, "There is no god but God, Lord of the Quran and its creator." Al-Kindī, The Governors and Judges of Egypt, ed. R. Guest, E. J. W. Gibb Memorial Series, vol. 19 (Leiden: E.J. Brill, 1912), 451; Ibn Abī al-Wafā'), al-Jawāhir al-mudiyya fì țabaqāt al-ḥanafiyya, ed. 'A. M. al-Ḥulw, 5 vols. (Cairo: Dār Iḥyā' al-Kutub al-'Arabiyya, 1398-1408/1978-88; repr. Giza: Hajr, 1413/1993), 3: 112; Ibn Ḥajar, Lisān al-mīzān, 7 vols. (Hyderabad: Majlis Dā'irat al-Ma`ārif, 1329-31; repr. Beirut: Mu’assasat al-A`lamī, 1406/1986), 5: 110.

19. Ibn Ab̄̄ Ya'lā, Ṭabaqāt al-ḥanābila, ed. 'A. al-'Uthaymīn, 3 vols. (n.p.: al-Amāna al-'āmma li-l-iḥtifāl bi-murūr mi'at 'ām 'alā ta'sīs al-mamlaka, 1419/1999), 1: 386. 


\section{IN SYRIA}

Al-Khațīb al-Baghdādī relates the story of Abū Mushir (مسهر) al-Dimashqī (d. 218/833), who was brought to al-Ma'mūn at al-Raqqa. He refused to profess the Quran created until the executioner's mat was brought before him. Rather than have him return to Damascus proclaiming that he had professed only from fear, al-Ma'mūn sent him to be imprisoned in Baghdad, where he died soon after. ${ }^{20}$

Some sources explicitly place al-Ma'mūn's question to Abū Mushir about the Quran in Damascus itself. ${ }^{21} \mathrm{Abu}$ al-' $\mathrm{C}$ rab, however, relates a long story of his being examined in Baghdad itself in the presence of the Hanafi Bishr al-Marīsī, the Mu'tazili Thumāma ibn Ashras, one 'Alī al-Dārī (unidentified by me), and others gathered by the governor Isḥāq ibn Ibrāhīm. ${ }^{22}$ Thumāma is commonly reckoned as having died in 213/828-29, casting doubt on the list of witnesses, but Ibn al-Jawzī relates a story in which he was killed in Mecca in revenge for his part in the killing of the rebel Aḥmad ibn Naṣr al-Khuzâ̄i in Baghdad; i.e., in $231 / 846 .^{23}$

Fahmī Jad'ān observes that Abū Mushir had earlier come to al-Ma'mūn's attention as qadi for the rebel Abū al-'Amayțar al-Sufyānī (seized Damascus in 196/811) and for lamenting that the prophet Dhū al-Qarnayn had built a wall to protect the people of Khurasan from Yājūj and Mājūj (Q 18:93-98) but not a wall to protect the people of Syria from the people of Iraq. ${ }^{24}$ Some medieval historians asserted that Abu Mushir's imprisonment had to do only with his involvement with Abū al-`Amayțar. ${ }^{25}$ Jad'ān accepts that Abū Mushir suffered over the Quran but guesses that the interview with al-Ma'mūn took place not in 218 in alRaqqa but the year before in Damascus, in 217/832. ${ }^{26}$ This accords with Ibn 'Asākir's two versions that expressly locate the interrogation in Damascus, and with al-Ya'qūbī's report that al-Ma'mūn left Egypt for Syria early in 217/832. ${ }^{27}$ Al-Ya'qūbī also reports a visit to Damascus in 218 in which he interrogated the people with regard to "justice and unity" (soon identified as two of the Mu'tazila's five leading principles), specifically the creation of the Quran. ${ }^{28}$ So far as I know, however, no other chronicle mentions a visit to Damascus in 218, so a beginning in 217 remains a possibility.

Abū al-Daḥdāḥ al-Dimashqī related in his Manāqib (in praise of Aḥmad ibn Abī al-Hawārī, the Damascene renunciant and traditionist [d. 246/860?]) from al-Husayn ibn Hāmid that al-Ma'mūn's letter came to Ishāq ibn Yahyā ibn Mu'ādh, commander (amīr) of Damascus, (directing him) to bring the traditionists to Damascus to test them. Therefore, he brought Hishām ibn 'Ammār, Sulaymān ibn 'Abd al-Raḥmān, 'Abd Allāh ibn Dhakwān, and Ahmmad

20. Ibn Sa`d, K. al-Tabaqāt al-kabìr, ed. E. Sachau et al., 9 vols. in 15 (Leiden: E.J. Brill, 1904-40), 7.2: $174=$ al-Ṭabaqāt al-kubrā, 9 vols. (Beirut: Dār Șādir, 1957-68), 7: 473; al-Khațīb al-Baghdādī, Tārīkh, 12: 351.

21. Al-Qāḍ̄i 'Tyāḍ, Tartīb, 3: 224, citing “al-Balkhī”; Ibn 'Asākir, Tārīkh madīnat Dimashq, ed. 'U. ibn Gh. al-'Amrawī, 80 vols. (Beirut: Dār al-Fikr, 1415/1995) 33: 436-37, 438; al-Dhahabī, Tārīkh, 15: 247-48 citing al-Șūlī.

22. Abū al-'Arab, Mihan, 446-47.

23. Ibn al-Jawzī, al-Muntazam, ed. Muh. 'A. 'Ațā and Mușt. 'A. 'Ațā, with N. Zarzūr, 18 vols. (Beirut: Dār al-Kutub al-'Tlmiyya, 1412/1992), 10: 255-56; Ibn Hajar, Lisān, 2: 84.

24. Jad'ān, Mihnna, 135-36. Indeed, his dialogue with al-Ma’mūn as reported by al-Khațīb al-Baghdādī includes a direct reference to Abū al-'Amayțar (Tärīkh, 12: 351).

25. Badr al-Dīn al-`Ayn̄̄, 'Iqd al-jumān, Topkapı Sarayı 2911, A8 (sub anno 218), citing Sibṭ Ibn al-Jawzī, Mir'àt al-zamān.

26. Jad`ān, Mihnna, 136.

27. Respectively, Ibn 'Asākir, Tārīkh 33: 436-38; al-Ya'qūbī, al-Tārīkh, ed. M. Th. Houtsma, 2 vols. (Leiden: E.J. Brill, 1883), 2: 569 = (Beirut: Dār Șādir, 1379/1960), 2: 466.

28. Al-Ya'qūbī, Tārīkh, 2 (Leiden): $571=2$ (Beirut): 467-68. 
ibn Abī al-Hawārī and tested them. His testing was not severe and they answered (as bidden) except for Ahmmad ibn Abī al-Hawārī. He took to being gentle with him, saying "Aren't the heavens created? Isn't the earth created?" But Ahmad refused to obey him, so he imprisoned him for a time in Dār al-Hijāra. Later he answered (as bidden), whereupon he released him. ${ }^{29}$

Since all four are said to have capitulated, this seems likely to be an accurate account. Hishām ibn 'Ammār (d. Damascus, 245/869?) was a significant traditionist (in five of the Six Books), denounced by Ahmad ibn Hanbal for holding the Quran to be created. ${ }^{30}$ Sulaymān ibn 'Abd al-Raḥmān (d. 233/847) was another Damascene traditionist (likewise in five of the Six Books), said to be honest but undiscriminating. ${ }^{31}$ 'Abd Allāh ibn Dhakwān is presumably the traditionist and Quran reciter 'Abd Allāh ibn Aḥmad ibn Bashīr ibn Dhakwān (d. 242/857). ${ }^{32}$ The implicit timeline of this story and the involvement of the governor, not the caliph directly, both tell against al-Ma'mūn's presence in Damascus in 218.

\section{IN EGYPT}

There may have been an Egyptian party that argued for a created Quran fifteen years or more before the beginning of the Inquisition. Ibrāhīm ibn 'Ulayya (d. 218/833) is said to have advocated a created Quran. He is also said to have debated with al-Shăfi $i_{\overline{1}}$ in both Baghdad and Fustat, although the particular topic mentioned is the nonrecurrent report (khabar al-wähid), rejected by the Mu'tazila. Al-Maqrīzī characterizes Ibn 'Ulayya as among the ghilmān, or devoted followers, of Ibn Abī al-Layth, later prosecutor of the Inquisition as qadi for Egypt; that is, the Hanafi Muhammad ibn Abī al-Layth (d. 250/864-5). ${ }^{33}$ Al-Khațîb al-Baghdādī, however, quotes the characterization of Șālih ibn Abī Șāliḥ, secretary to al-Layth (ibn Sa'd, d. 175/791), that Ibn 'Ulayya was among the ghilmān of the proto-Mu'tazili Abū Bakr ibn Kaysān al-Așamm (Basran, d. 200/815-16?), confirmed by the Mu'tazili biographer 'Abd al-Jabbār. ${ }^{34}$ One source of confusion is that the Hanafi qadi Ibn Abī al-Layth is also sometimes identified as "al-Așamm." 35 Ibn 'Ulayya was more likely associated with the Mu'tazili al-Așamm than the Hanafi qadi.

The Inquisition in Egypt formally began with the arrival of a letter from al-Faḍl ibn Marwān on behalf of al-Ma'mūn to the governor of Egypt, Kaydur. It was dated 21 Jumādā I 218/14 June 833; i.e., a month or two after the commencement of the Inquisition in Baghdad. It called for similar measures to those taken before: the examination of witnesses, qadis, traditionists, and jurisprudents, depriving recalcitrants of their positions or of permission to teach or give opinions. Al-Rabī̄ ibn Sulaymān al-Jīzì (d. 256/870) was present when the qadi Hārūn ibn 'Abd Allāh thanked God for sparing him what he had inflicted on others, presumably with reference to the Inquisition. The prayer was reported to Ibn Abī Duwād (by whom,

29. Al-Dhahabī, Tārīkh, 18 (241-250 AH): 54.

30. See F. Sezgin, Geschichte des arabischen Schrifttums, 17 vols. (Leiden: E.J. Brill, 1967-84; Frankfurt: Institut für Geschichte der Arabisch-Islamischen Wissenschaften, J. W. Goethe Universität, 1995-2015), 1: 111-12; and al-Dhahabī, Tārīkh, 18: 520-28 with further references.

31. See al-Dhahabī, Tārīkh, 18: 185-56 with further references.

32. See al-Dhahabī, Tārīkh, 18: 307-10 with further references.

33. Al-Maqrī̄īi, K. al-Muqaffā al-kabīr, ed. M. al-Ya`lawī, 8 vols. (Beirut: Dār al-Gharb al-Islāmī, 1991), 1: 102.

34. Al-Khațīb al-Baghdādī, Tārīkh, 6: 513; 'Abd al-Jabbār, Faḍl al-i'tizāl, in Faḍl al-i'tizāl wa-tabaqāt al-mu'tazila, ed. F. Sayyid (Tunis: al-Dār al-Tūnusiyya, 1393/1974), 129-350, at 267. Among the works of al-Așamm is a Kitāo Khalq al-Qur'ān; see Ibn al-Nadīm, al-Fihrist, ed. A. F. Sayyid, 4 vols, Silsilat al-nușūṣ al-muhaqqaqa, 2nd ed. (London: Mu'assasat al-Furqān li-1-Turāth al-Islāmī, 1435/2014), 1: 594.

35. Al-Dhahabī, Tārìkh, 18: 493. 
al-Rabī ${ }^{\complement}$ does not say) and so Hārūn lost his position. ${ }^{36}$ However, we also have a report that Hārūn was not formally deposed until 226/840. ${ }^{37}$

Al-Ma'mūn had a number of traditionists and jurists brought from Egypt to Baghdad. According to al-Khațīb al-Baghdādī, al-Ma'mūn put al-Ḥārith ibn Miskīn (d. 250/864) in prison for refusing to affirm that the Quran was created, there to remain until al-Mutawakkil released him and made him qadi for Egypt. ${ }^{38}$ Another story is told by the Egyptian Yūsuf ibn Yazīd al-Qarāṭ̂̄is̄ (d. 287/900): that al-Ḥārith displeased al-Ma'mūn in early 217/Spring 832 by publicly denouncing his lieutenants over Egypt, Ibrāhīm ibn Tamīm and Aḥmad ibn Muḥammad ibn Asbāt. Al-Ma'mūn ordered him to sell his possessions and take up residence in Baghdad, where he stayed (with the traditionist al-Hasan ibn 'Abd al-'Azīz al-Jarawī, d. Baghdad, Rajab 257/May or June $871^{39}$ ) until late in the reign of al-Wāthiq, who released him to go where he pleased. ${ }^{40}$ Al-Ya'qūbī relates a story by which al-Hāarith displeased al-Ma'mūn by giving him a disapproving juridical opinion, asserting that some Egyptians had rebelled against an oppressor so that their blood and property were inviolable. ${ }^{41}$

It seems plausible that al-Hārith's confinement was independent of the Inquisition. For one, Ahmad ibn Hanbal is notably unconcerned with him as a fellow resister. His only quoted comment is from his response to a letter from Yahyā ibn Khāqān, the vizier, asking him about al-Hārith ibn Miskīn, qadi for Fustat: "I have heard of him nothing but good." 42 For another, al-Ḥārith began sitting as judge in Cairo on Monday, 10 Jumādā II 237/9 December 851, four months before al-Mutawakkil ordered the body of Aḥmad ibn Nașr taken down in Shawwāl of that year. ${ }^{43}$ There is even a report of his returning to Fustat in 233/847-8, when Ibn Abī al-Layth, still qadi, considered examining him but was dissuaded by the argument that he had not been examined by the caliph in Baghdad (implying that the caliph saw no need to examine him). ${ }^{44}$

Contrarily, there are also reports that the Inquisition was initiated in Egypt only on the arrival of a letter from al-Mu'tașim, ordering the examination of witness-notaries, traditionists, and others. ${ }^{45}$ The incumbent qadi, Hārūn ibn 'Abd Allāh, begged off; therefore, Ibn Abī Duwād wrote to Ibn Abī al-Layth, ordering him to extend the Inquisition. Abū al-`Arab mentions three interrogated by Ibn Abī al-Layth in the mosque of Fustat, who answered as bidden out of taqiyya (precautionary dissimulation) to avoid being deported: Abū al-Țāhir, Abū Ja'far al-Aylī, and Yaḥyā ibn 'Abd Allāh ibn Bukayr. ${ }^{46}$ The first two were prominent disciples of Ibn Wahb (Egyptian, d. 197/813): Ahmad ibn 'Amr ibn al-Sarj (d. 250/864) and Hārūn ibn Sa ${ }^{c} \bar{i} d$ (d. 253/867), respectively, while Yaḥyā ibn Bukayr (d. 231/845) was a

36. Ibn Yūnus, apud al-Kindī, Governors, 448.

37. Al-Kindī, Governors, 448-49.

38. Al-Khațīb al-Baghdādī, Tārikh, 9: 111.

39. Al-Hasan had likewise been brought to Baghdad for political reasons. His father and brother had been lords of Tinnis, so al-Hasan's offense presumably likewise had to do with resistance to al-Ma'mūn in the Fourth Civil War. See al-Dhahabī, Tärīkh, 19 (251-260 AH): 108-9 with further references.

40. Al-Qāḍī 'Iyāọ, Tartīb, 4: 33-35; al-Dhahabī, Tārīkh, 18: 212-14.

41. Al-Ya'qūbī, Tārīkh, 2 (Leiden): 569 = 2 (Beirut): 466. Al-Ma’mūn retorted that al-Ḥārith was a goat (tays, meaning foolish) and Mālik goatish, then had the rebel leaders brought to Baghdad anyway.

42. Al-Khațīb al-Baghdādī, Tārìkh, 9: 112.

43. Al-Kindī, Governors, 468 (al-Ḥārith); al-Ṭabarī, Annales, ed. M. J. de Goeje et al., 3 vols. in 15 (Leiden: E.J. Brill, 1879-1901), 3: 1413 (Aḥmad ibn Nașr). Ibn al-Jawzī (Muntaẓam, 11: 251) reports also a letter in this year ordering the release of all those whom al-Wāthiq had imprisoned over the creation of the Quran, but regrettably without naming a month.

44. Al-Kindī, Governors, 462.

45. Al-Kindī, Governors, 447; al-Dhahabī, Tārīkh, 15: 27, citing al-Musabbiḥ̄i (d. 420/1029), Akhbār Miṣr.

46. Abū al-'Arab, Miḥan, 445. 
respected Egyptian transmitter of Mālik's Muwatța'. Al-Kindī mentions three whose deportation to Iraq Ibn Abī al-Layth oversaw: Nu'aym ibn Hammād, al-Buwayțī, and a certain Khushnām, a traditionist (whose name, unfortunately, I have been unable to discover in any biographical dictionary). ${ }^{47} \mathrm{We}$ also have an explicit report that $\mathrm{Nu}^{\complement}$ aym ibn Hammād was deported to Iraq in 223 or 224, suggesting that Ibn Abī al-Layth became prosecutor for Ibn Abī Duwād in 223 or 224 without yet becoming qadi. ${ }^{48}$ The precise date of the letter quoted from al-Ma'mūn suggests that such a letter was actually received and preserved; moreover, al-Tabarī clearly indicates that al-Ma'mūn promulgated the Inquisition in all directions. Perhaps the Inquisition remained a dead letter in Egypt until renewed by al-Mu'tașim, as it remained forever a dead letter in Khurasan and elsewhere.

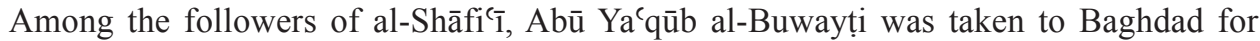
refusing to testify that the Quran was created. He died in prison there in 231/845-6. According to Ibn 'Abd al-Barr, he fell victim to the envy of Ibn Abī al-Layth, who had dispatched him to Baghdad. ${ }^{49}$ There are also reports that he was denounced to the authorities by rivals among the followers of al-Shāfi ${ }^{\top} \overline{1}$, mainly Harmala (d. 226/840-1), al-Muzanī (d. 264/877-8), and one of al-Shāfí̄'s's sons - it would seem the Muhammad who died in 231/846. ${ }^{50} \mathrm{Al}-\mathrm{Rab}^{\mathrm{c}}$ ibn Sulaymān (presumably al-Murādī, d. 270/884) named them among those who denounced him - it is not stated precisely when or what he refused to say, but it can hardly be other than affirming the Quran created. ${ }^{51}$ The Baghdadi Abū Ja'far al-Tirmidhī (d. 295/907) related that al-Buwayți himself had said, "All the people save three are innocent of my blood: Harmala, al-Muzanī, and one other." ${ }^{52}$ Harmala and al-Muzan̄̄'s complicity may be confirmed by the report that, on becoming qadi, al-Hārith ibn Miskīn had both the Hanafis and Shafí is expelled from the mosque. ${ }^{53}$

Another sometime follower of al-Shāfi $\bar{i}_{\overline{1}}$ who suffered in the Inquisition was Muhammad ibn 'Abd Allāh ibn 'Abd al-Hakam (d. 268/882). By one account, he was sent before Ibn Abī Duwād in Iraq, still refused to affirm that the Quran was created, and was then returned to Egypt. ${ }^{54}$ According to another, more plausible account, he was flogged for his beliefs in Egypt, then hid himself. ${ }^{55}$ Al-Kindī mentions his proclaiming the Quran created as he was paraded through the streets, in like manner as the reputable traditionist Hārūn ibn Sa $\mathrm{Sa}^{\top} \overline{\mathrm{d}}$ (d. 253/867). ${ }^{56}$

Aṣbagh ibn al-Faraj (d. 225/840?), copyist to Ibn Wahb, was ordered by al-Mu'tașim to be brought to him in Baghdad. Aṣbagh fled to Ḥalwān and hid there till he died. ${ }^{57}$ Other Egyptians who reportedly hid or fled were Muhammad ibn Sālim al-Qațtān (otherwise unknown

47. Al-Kindī, Governors, 447. I have come across a sororal nephew to Bishr al-Hāẫ named Khushnām, who may have transmitted sayings from Bishr in Egypt; al-Khațīb al-Baghdādī, Tārīkh, 7: 43.

48. Al-Khațīb al-Baghdādī, Tārīkh, 15: 429.

49. Ibn 'Abd al-Barr, al-Intiqà)' (Cairo: Maktabat al-Qudsī, 1350, repr. Beirut: Dār al-Kutub al-'Tlmiyya, n.d.), $110-11$

50. Al-Khațīb al-Baghdādī, Tārīkh, 4: 325, citing Abū Sac̄ì ibn Yūnus.

51. Al-Dhahab̄i, Tārīkh, 17 (231-240 AH): 423; al-Subkī, Ṭabaqāt al-shāficiyya al-kubrā, ed. M. M. al-Ṭanāḥī and 'A. al-Ḥulw, 10 vols. (Cairo: 'T̄sā al-Bābī al-Ḥalabīi, 1964-76), 2: 164.

52. Al-Dhahabī, Tārīkh, 17: 423-24.

53. Al-Kindī, Governors, 469.

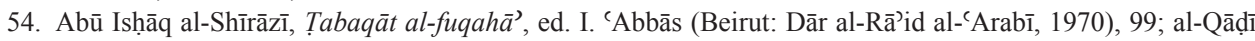
'Iyāụ, Tartīb, 4: 164 .

55. Abū al-'Arab, Mihan, 437; al-Dhahabī, Tārīkh, 20 (261-280 AH): 170. But there may have been some confusion with his brother 'Abd al-Ḥakam, whose flogging in the mosque is reported by al-Qāḍī 'Iyāḍ, Tartīb, 4: 157.

56. Abū al-'Arab, Mihan, 448; Kindī, Governors, 451-52.

57. Al-Dhahabī, Tārīkh, 16: 99, citing Ibn Qudayd. 
to me), Abū Yaḥyā Zakariyyā̄ ibn Yahyāa al-Waqār (d. 254/868?), and Zayd ibn Bashīr (d. 240/854-5?), who first hid in his house and then fled to Tunis in 232/846-7 to escape from Ibn Abī al-Layth. ${ }^{58}$ Al-Kindī also mentions two traditionists who fled to Yemen to escape from Ibn Abī al-Layth: Yūsuf ibn Abī al-Tayba and Ahmad ibn Șālih (d. 248/862-3). He states that the early mystic Dhū al-Nūn (d. 246/861?) initially hid, then reappeared, was arrested, and confessed as bidden. ${ }^{59}$ There is also a story that Dhū al-Nūn was denounced for zandaqa (secret unbelief) by some fellow Egyptians led by the Maliki 'Abd Allāh ibn 'Abd al-Hakam (or rather, presumably his son Muhammad). He was eventually hauled before the governor of Egypt, and then sent to Baghdad for trial before the caliph al-Mutawakkil, who acquitted him. ${ }^{60}$ But al-Khațî̉b al-Baghdādī’s reports of his interactions with al-Mutawakkil and the vizier Ibn Aktham include no hint of arrest and trial. ${ }^{61}$ To be sure, trial before alMutawakkil in 242/856-7 is not incompatible with persecution over the Quran fifteen or twenty years earlier. Abū Isḥāq al-Shīrāzī states that the prominent Maliki Ibn al-Mawwāz (d. 269/883?) "was sought in the Inquisition and so left Alexandria, fleeing to Syria, where he stuck to a certain fortress until he died." 62 However, this reference to the Inquisition seems misplaced, and more likely Ibn al-Mawwāz hid in connection with his refusal to endorse Ahmad ibn Țūlūn's deposition of the shadow caliph al-Muwaffaq in 269/882. ${ }^{63}$

\section{IN ISFAHAN}

I have remarked upon Bakkār ibn al-Hasan's persecution in Isfahan earlier. ${ }^{64}$ This Hanafi jurisprudent (d. 233/847-8 or 238/852-3) was examined, refused to affirm that the Quran was created, and was about to be expelled from the city when news came of al-Wāthiq's death. The guards were then withdrawn from his house and women and children bandied about a vulgar rhyme celebrating Bakkār's vindication and the humiliation of his persecutor, the Hanafi qadi Hayyān ibn Bishr (d. 237/851-2?). ${ }^{65}$ Evidently, the Inquisition had to be renewed at the accession of every new caliph, and it was known that al-Mutawakkil would not renew it. This is the only occasion on which Abū al-Shaykh takes notice of the Inquisition, suggesting moreover that it was enforced in Isfahan only under al-Wāthiq; possibly, other ulema acquiesced at the time.

58. Al-Kindī, Governors, 453; al-Qāḍī Tyāḍ, Tartīb, 4: 37, 100.

59. Al-Kindī, Governors, 453. See also Jad'ān, Mihnna, 157.

60. Al-Sulamī, Mihan al-șüfiyya, apud al-Dhahabī, Tārīkh, 18: 267.

61. Khațīb al-Baghdādī, Tārīkh, 9: 375-77. On Dhū al-Nūn, see al-Dhahabī, Tārīkh, 18: 265-70 with further references, to which add Ibn 'Asākir, Tārīkh, 17: 398-442.

62. Al-Shīrāzī, Țabaqāt, 153.

63. See al-Qāḍī Iyāạ, Tartīb, 4: 168.

64. Melchert, "Religious Policies," 320-21.

65. Abū al-Shaykh, Ṭabaqāt al-muhaddithīn bi-Ișbahān, ed. 'A. 'A. Ḥ. al-Balūshī, 4 vols. (Beirut: Mu'assasat al-Risāla, 1407-12/1987-92), 2: 131-32; Abū Nứaym al-Ișbahānī, Geschichte Ișbahans: Nach der Leidener Handschrift, ed. S. Dedering, 2 vols. (Leiden: E.J. Brill, 1931-34), 1: 238. It is possible that Hayyān was not actually the qadi for Isfahan but rather overseer of its mazālim court, for Abū Nu'aym (Geschichte Ișbahans, 1: 82) states that Isfahan was without a qadi for ten years under Ibn Abī Duwād; the first qadi under al-Mutawakkil was one Abū 'Alī Aḥmad ibn al-Wazīr (d. 278/891-2). On Ḥayyān, see further al-Dhahabī, Tārīkh, 17: 147 with further references, to which add Ibn Abī al-Wafā', Jawāhir, 2: 158. 


\section{IN AFRICA}

The province of Africa was practically independent from the time of the Fourth Civil War. Consequently, the ups and downs of the Inquisition there have mainly to do with the religious policies of the Aghlabids in Qayrawan, not of the Abbasid caliphs.

Before Abu Ja'far Ahmmad ibn al-Aghlab, brother to the ruler Muhammad ibn al-Aghlab (r. 226-42/840-56) and formally his crown prince (wali al-' $a h d$ ), asserted authority in $231 / 846$ and immediately established the Inquisition, ${ }^{66}$ as observed by Martin Hinds, ${ }^{67}$ the Hanafi-Maliki jurisprudent Asad ibn al-Furāt (d. Sicily, 213/828) was said to have professed the created Quran (regarding which the well-known Maliki jurisprudent Sahnūn said, "He did not say so; but even if he did say so, we do not" ${ }^{68}$ ). 'Abd Allāh ibn Abī Hassān, who heard hadith from Mālik, came across a debate in progress before the ruler al-Aghlab ibn Ibrāhīm ibn Aghlab (r. 223-26/838-41) over whether the Quran was created. 'Abd Allāh ibn Abī Hassān was known to the participants to hold that it was not created, but unfortunately the two opponents "al-Ja'far $\vec{\imath}$ " and "al-'Anbar $\vec{\imath}$ " are not identifiable. ${ }^{69}$ At least this shows that, as the Inquisition was raging in Egypt, so its theological occasion was being discussed in Africa, although the caliphs could not compel anyone to impose their doctrines on the ulema there. The blind Maliki Mūsā ibn Mu'āwiya (d. 225/840?) was interrogated by the Mưtazili qadi for Qayrawan and would only quote various shaykhs who had denied that it was created. The qadi insulted him, saying "God has blinded your heart as he has blinded your eyes," but no punishment is mentioned. ${ }^{70}$ Under Abū Ja'far ibn al-Aghlab, Saḥnūn (d. 240/854) was the most prominent victim; he was put under house arrest, but then was appointed qadi for Qayrawan by Muhammad ibn al-Aghlab after he reasserted his authority the next year. ${ }^{71}$ Saḥnūn himself had Ibn Abī al-Jawād, the qadi who sentenced him, repeatedly flogged until he sickened from it and died in prison, although the occasion was ostensibly financial, not the qadi's prosecution of the Inquisition. ${ }^{72}$ Irrespective of the Inquisition, violent HanafiMaliki rivalry in Africa continued throughout the century, reaching a peak under the Hanafi qadi Ibn 'Abdūn (d. 300/912-13?), who in 275/888-9 had his Maliki predecessor Ibn Țālib killed either by poison or having two slaves stamp on his belly. ${ }^{73}$

\section{CONCLUSION}

By scholarly consensus, the chief consequence of the Inquisition was to discredit caliphal claims to define Islamic orthodoxy. Secondarily, it occasioned Ahmad ibn Hanbal's heroic defiance and hence, in the medium term, his own preeminence as arbiter of orthodoxy. This brief survey of the Inquisition outside Baghdad does not call into question either of these conclusions. It does call into question, however, the traditional start date of 218/833, which

66. See M. Talbi, L'émirat aghlabide (Paris: Adrienne-Maisonneuve, 1966), 222-31.

67. Hinds, "Mihnna," 7: 4b.

68. Abū al-'Arab, Classes des savants de l'Ifrîqûya, ed. M. Ben Cheneb, Publications de la Facultée des lettres d'Alger, Bulletin de correspondance africaine, vol. 51 (Paris: Leroux, 1915), 82. Cf. Abū Bakr al-Mālikī, K. Riyāọ al-nufūs, ed. B. al-Bakkūsh and M. al-'Arūsī al-Muțțawwī, 3 vols. (Beirut: Dār al-Gharb al-Islāmī, 1401-3/198183), 1: 264-65.

69. Abū Bakr al-Mālikī, Riyāẹ, 1: 286-87.

70. Al-Qāḍī 'Iyāḍ, Tartīb, 4: 94-95.

71. See Abū al-'Arab, Miḥan, 449-52.

72. Al-Qāḍ̄i 'Iyāḍ, Tartīb, 4: 65-66, 69-72. Two years had passed between Ibn Abī al-Jawād's dismissal and Sahnūn's assumption of the judgeship, as remarked by Talbi, Émirat, 233-34.

73. Al-Qāḍ̄ 'Iyāḍ, Tartīb, 4: 325-27; Talbi, Émirat, 285. Al-Qāḍ̄ 'Tyāḍ (Tartīb, 4: 356) also names four other Malikis Ibn 'Abdūn had put to death. 
al-Ṭabarī gives for al-Ma'mūn's letter to the governor of Baghdad, Ishāq ibn Ibrāhīm. ${ }^{74}$ As noted, there are reports that al-Ma'mūn or his lieutenants were already asking ulema about the Quran the year before in Damascus and Kufa.

The geographical distribution of reported prosecutions confirms one interpretation of the Inquisition, namely, that it was about putting the ulema in their place. Basra, Kufa, Medina, Mecca, Damascus, Fustat - these are exactly the places where a class of experts in hadithbased law went back the longest. The Jibal and Khurasan, where we do not hear of prosecutions, became significant centers no earlier than during the lifetime of al-Ma'mūn himself. ${ }^{75}$ Moreover, there have been cases in which someone was apparently chosen for testing just because he had previously defied al-Ma'mūn (Abū Nu'aym in Kufa, Abū Mushir in Damascus) and those in which it is uncertain whether someone's suffering had anything to do with the Inquisition as opposed to other acts of defiance (Abū Bakr ibn Abī Uways in Medina, al-Hārith ibn Miskīn in Egypt). Plainly, the emerging class of ulema were potentially dangerous foci of discontent. ${ }^{76}$ Finally, the numerous contradictory accounts (and failure of numerous sources to report much on the Inquisition at all) suggest that the Inquisition caused considerable consternation for the Sunni ulema, embarrassed both by what they considered so obviously a wrongheaded policy from the caliphs they felt dutybound to support and by the many prominent traditionists and jurisprudents who capitulated.

74. Al-Ṭabarī, Annales, 3: 1112.

75. See S. C. Lucas, Constructive Critics, Hadīth Literature, and the Articulation of Sunni Islam: The Legacy of the Generation of Ibn $\mathrm{Sa}^{\mathrm{c}}$, Ibn Ma $\mathrm{i}$, and Ibn Hanbal, Islamic History and Civilization, Studies and Texts, vol. 51 (Leiden: Brill, 2004), chap. 8.

76. The classic exposition of caliphal claims to supreme religious authority is P. Crone and M. Hinds, God's Caliph: Religious Authority in the First Centuries of Islam, University of Cambridge Oriental Publications, vol. 37 (Cambridge: Cambridge Univ. Press, 1986). Caliphal patronage of the ulema before the Inquisition is documented by M. Q. Zaman, Religion and Politics under the Early 'Abbāsids: The Emergence of the Proto-Sunnī Elite, Islamic History and Civilization, Studies and Texts, vol. 16 (Leiden: Brill, 1997), purporting to refute Crone and Hinds but tending to knock down only a straw man version of their argument. 